\title{
SHADOW TEACHER FOR SPECIAL NEEDS STUDENTS: CASE STUDY CLASS VI TAMAN MUDA IBU PAWIYATAN YOGYAKARTA
}

\author{
Maratul Qiftiyah ${ }^{1}$, Wina Calista ${ }^{2}$ \\ ${ }^{1,2}$ Universitas Islam Negeri Sunan Kalijaga Yogyakarta
}

\begin{abstract}
This research is to describe the shadow teacher for students with special needs at Taman Muda Ibu Pawiyatan Yogyakarta Elementary School. This type of research is qualitative research. This is a qualitative descriptive study which produces descriptive data in the form of words based on detailed and in-depth field research. The subject of this study was the shadow teacher in class VI. Data collection techniques using observation and interviews. As for the data analysis which is done which includes: data reduction, data presentation, and concluding. Based on the results of the study it can be concluded that the shadow teacher who accompanies students with special needs (mild intellectual impairment) in class VI is doing an authoritarian accompaniment. The mentoring makes students experience pressure when learning, it is not uncommon for students to cry, and leave the classroom when learning. Also, the shadow teacher's actions disturb other students. That is what some parents in class IV agreed not to involve shadow teachers in the learning process in class.
\end{abstract}

Keyword: Shadow Teacher, with Special Needs.

\begin{abstract}
Abstrak: Penelitian ini adalah untuk mendeskripsikan shadow teacher bagi siswa berkebutuhan khusus di SD Taman Muda Ibu Pawiyatan Yogyakarta. Jenis penelitian yang dilakukan adalah penelitian kualitatif. Penelitian ini bersifat deskriptif kualitatif yang menghasilkan data deskriptif berupa kata-kata berdasarkan penelitian yang dilakukan di lapangan secara terperinci dan mendalam. Subjek dalam penelitian ini adalah shadow teacher pada kelas VI. Teknik pengumpulan datanya menggunakan observasi dan wawancara. Adapun analisis data yang dilakukan yaitu meliputi: reduksi data, penyajian data, dan penarikan kesimpulan. Berdasarkan hasil penelitian dapat disimpulkan bahwa shadow teacher yang mendampingi siswa berkebutuhan khusus (gangguan intelektual ringan) di kelas VI melakukan pendampingan bersikap otoriter. Pendampingan tersebut membuat siswa mengalami tekanan pada saat belajar, tidak jarang siswa menangis, dan keluar kelas pada saat pembelajaran. Selain itu, tindakan shadow teacher mengganggu siswa yang lainnya. Hal itulah yang kemudian sebagian orang tua di kelas IV membuat kesepakatan untuk tidak melibatkan shadow teacher dalam proses pembelajaran di kelas.

Kata Kunci: Shadow Teacher, Berkebutuhan Khusus.
\end{abstract}

\footnotetext{
I Universitas Islam Negeri Sunan Kalijaga Yogyakarta, Email: maratulqiftiyah @amail.com

${ }^{2}$ Universitas Islam Negeri Sunan Kalijaga Yogyakarta, Email: winacalista回gmail.com
} 


\section{PENDAHULUAN}

Ilmu pengetahuan dan teknologi berkembang pesat dari tahun ke tahun, begitu juga dengan pendidikan dari tahun ke tahun semakin berkembang. Pendidikan dilakukan untuk memenuhi kebutuhan manusia guna mencapai kualitas hidup yang lebih baik dan semua orang berhak atas pendidikan, tanpa terkecuali (Rahmaniar, 2016, hlm. 1253). Orang tua harus memperluas dan terus meningkatkan pengetahuan mereka tentang cara untuk mendidik anak-anak, sehingga anak yang mereka lahirkan menerima pendidikan yang layak (Umroh, 2019, hlm. 209). Salah satu solusi yang diambil untuk meminimalkan kesenjangan dan perlakuan diskriminatif dalam memperoleh peluang pendidikan terutama untuk anak-anak penyandang cacat atau anak-anak dengan kebutuhan khusus adalah melalui pendidikan inklusif. Pendidikan inklusif memiliki prinsip dasar bahwa sejauh mungkin, semua anak harus belajar bersama-sama tanpa memperhatikan kesulitan atau perbedaan yang mungkin ada pada mereka (Yasa \& Julianto, 2017, hlm. 121).

Dalam pembelajaran inklusif, setiap siswa berkebutuhan khusus didampingi oleh shadow teacher atau guru pendamping. Shadow teacher atau guru pendamping merupakan guru yang ditugaskan untuk mendampingi di sekolah dan telah menerima pelatihan khusus tentang cara menangani siswa berkebutuhan khusus dan harus memiliki kompetensi dalam berurusan dengan siswa berkebutuhan khusus (Wardani dkk, 2018, hlm. 2). Di sekolah dasar reguler banyak ditemukan siswa yang mengalami kesulitan belajar dan mendapatkan prestasi rendah, terutama di kelas kecil atau rendah. Namun, dari sudut pandang orang lain beranggapan bahwa siswa yang mengalami kesulitan belajar disebabkan oleh siswa yang malas belajar, nakal, bodoh, dan tidak mau mencoba. Bahkan, ini bisa terjadi karena faktor internal dan eksternal. Oleh karena itu, untuk meminimalkan kesulitan yang dihadapi siswa, perlu difasilitasi dengan kehadiran shadow teacher di sekolah. Shadow teacher memiliki tugas untuk melayani siswa berkebutuhan khusus yang memiliki kesulitan belajar baik karena kekurangan fisik, mental, emosional atau intelektual di sekolah inklusif sehingga potensi mereka dapat dilayani secara maksimal.

Penelitian sebelumnya yang membahas efektivitas penyelenggaraan kelas inklusif adalah Berry (2006, hlm. 489-529), yang menemukan bahwa kelas inklusif yang efektif berasal dari keyakinan yang dimiliki guru tentang kepercayaan dan perlindungan dalam meningkatkan prestasi akademik siswa. Penelitian lain yang dilakukan oleh Elisa dan Syafrida (2013, hlm. 2) menemukan bahwa ada beberapa faktor yang mempengaruhi efektivitas pembelajaran inklusif di sekolah, yaitu: faktor guru, yang terdiri dari latar belakang guru, pandangan tentang anak berkebutuhan khusus, tipe guru, keyakinan guru, empati guru, dan gender guru. Faktor pengalaman, terdiri dari pengalaman mengajar dan pengalaman kontak dengan anak-anak berkebutuhan khusus. Faktor pengetahuan terdiri dari tingkat pendidikan guru, pelatihan, pengetahuan, dan kebutuhan belajar guru, serta faktor lingkungan terdiri dari dukungan sumber daya, dukungan orang tua dan keluarga serta sistem sekolah.

Masalah penugasan shadow teacher yang ditemukan berdasarkan pengamatan dan wawancara di SD Taman Muda Ibu Pawiyatan Yogyakarta, belum diidentifikasi secara menyeluruh sebagaimana mestinya. Pelaksanaan tugastugas yang tidak teridentifikasi ini berjalan secara tidak seragam antara satu sekolah dengan yang lainnya. Selain itu, ketidaksiapan sekolah menerapkan program pendidikan inklusif membuat penyesuaian terhadap ketersediaan sumber daya manusia (SDM), salah satunya adalah ketersediaan shadow teacher. Hal ini dapat mengakibatkan keterbatasan dalam menyediakan program pendampingan 
belajar bagi siswa ABK, sehingga banyak siswa yang belum menerima layanan pendidikan sesuai dengan kebutuhan dan kemampuan mereka serta masalah siapa yang memegang peran lebih besar bagi siswa ABK di sekolah inklusif. Seringkali, siswa berkebutuhan khusus datang ke sekolah tidak berpartisipasi dalam kegiatan belajar di kelas besar, tetapi akan terus didampingi oleh shadow teacher di kelas sumber kecuali mata pelajaran kesenian dan olahraga.

Peran shadow teacher dalam pendidikan anak berkebutuhan khusus adalah untuk membantu dalam mencapai target pendidikan yang telah dirancang oleh guru kelas. Selain itu juga harus lebih memahami kondisi dan perkembangan kemampuan anak. Dalam praktiknya, shadow teacher berada di sebelah anak dan mengamati perkembangan anak setiap hari selama kegiatan anak di sekolah. Lebih dari itu, shadow teacher tidak hanya bertindak sebagai pendamping anak-anak di sekolah, tetapi juga membantu memantau perkembangan anak-anak di rumah.

$$
\text { Berdasarkan hasil studi }
$$
pendahuluan di sekolah inklusif SD Taman Muda Ibu Pawiyatan Yogyakarta diketahui bahwa yang berperan menjadi shadow teacher bisa guru atau wali dari siswa yang berkebutuhan khusus. Hal ini berarti bahwa sekolah memberikan kebebasan kepada orang tua dari siswa berkebutuhan untuk memilih shadow teacher untuk mendampingi siswa berkebutuhan khusus dalam proses pembelajaran di kelas. Dari siswa kelas I-VI mereka yang cenderung siswa berkebutuhan khusus memiliki shadow teacher masing-masing baik guru, orang tua, mahasiswa, maupun shadow teacher khusus seperti psikolog. Hal itu disesuaikan dengan kondisi atau jenis gangguan siswa dan keputusan orang tua siswa. Dari keberagaman shadow teacher yang mendampingi siswa berkebutuhan khusus selama proses pembelajaran berlangsung tentu akan mempengaruhi proses pendampingan siswa, seperti guru atau psikolog yang memang sudah memiliki keahlian dibidang tersebut. Ini berbeda dengan shadow teacher yang tidak memiliki pemahaman sebelumnya seperti orang tua, mahasiswa, atau umum. Menyikapi hal tersebut sekolah yang berlatar belakang sebagai sekolah inklusi mencoba mengoptimalkan kemampuan shadow teacher dengan memberikan bimbingan atau arahan kepada shadow teacher yang dilakukan setiap satu bulan sekali. Hal ini tentu bertujuan untuk melatih atau memberikan informasi terkait pendampingan kepada anak berkebutuhan khusus yang memiliki berbagai macam jenis dan kebutuhan.

Namun, fakta dilapangan sebagaimana hasil observasi di kelas pada pembelajaran matematika di SD Taman Muda Ibu Pawiyatan ditemukan bahwa shadow teacher selaku orang tua yaitu ibu dari salah satu siswa dengan gangguan intelektual melakukan pendampingan secara otoriter, menggunakan nada yang keras dan kasar. Sikap shadow teacher tersebut tentu membuat siswa berkebutuhan khusus menjadi tertekan karena adanya tekanan belajar yang tidak membuat mereka nyaman. Selain itu, sikap shadow teacher juga menganggu kegiatan belajar mengajar yang terjadi di kelas. Adanya permasalahan tersebut maka penelitian ini bertujuan untuk menganalisis secara mendalam terkait problem yang terjadi di sekolah inklusi.

\section{METODOLOGI PENELITIAN}

Penelitian ini adalah penelitian kualitatif dengan pendekatan studi kasus. Adapun tujuan penelitian adalah untuk mendeskripsikan tindakan shadow teacher terhadap siswa berkebutuhan khusus di sekolah inklusi. Sehingga subjek dalam penelitian ini adalah shadow teacher yang ada di kelas VI. Penelitian dilakukan di SD Taman Muda Ibu Pawiyatan. Teknik pengumpulan data yang digunakan dalam penelitian ini adalah wawancara dan observasi. Observasi dilakukan di lingkungan sekolah inklusif yang dituju baik di dalam maupun di luar kelas. Kelas 
yang diteliti yaitu kelas VI, kegiatan pengamatan berlangsung selama proses belajar mengajar, dengan melihat bagaimana shadow teacher dalam melayani anak-anak berkebutuhan khusus dan kegiatan anak-anak di luar kelas seperti ketika beristirahat atau bermain dengan teman-temanya (kegiatan sosialisasi), mengikuti kegiatan ekstrakurikuler, dan lain sebagainya. Melihat sejauh mana shadow teacher melaksanakan program yang telah direncanakan dan masalah apa saja yang dihadapi saat memberikan layanan kepada anak-anak berkebutuhan khusus.

Wawancara digunakan untuk memperoleh data terkait dengan pelayanan dalam membimbing anak-anak berkebutuhan khusus di SD Taman Muda Ibu Pawiyatan. Keabsahan data dalam penelitian menggunakan triangulasi sumber (Sugiyono, 2010, hlm. 337). Teknik analisis data di dalam penelitian ini dengan menggunakan model analisis Miles, Huberman, dan Saldana (2014, hlm. 30-32) yaitu reduksi data, penyajian data, dan penarikan kesimpulan.

\section{HASIL PENELITIAN DAN PEMBAHASAN}

Keberadaan sekolah inklusif bukan hanya sekedar tempat eksistensi sebuah sekolah di suatu daerah. Akan tetapi, tanggung jawab besar ditanggung oleh sekolah inklusif untuk memberikan layanan yang optimal bagi siswa mereka, terutama anak-anak dengan kebutuhan khusus (Wardah, 2019, hlm. 97). Memahami pendidikan inklusif, Smith (2012, hlm. 45) mendefinisikan bahwa pendidikan inklusif adalah penggabungan anak-anak penyandang cacat (orang-orang yang memiliki hambatan/kelainan) ke dalam program-program sekolah. Konsep inklusi berkaitan langsung dengan anak-anak yang memiliki hambatan yang biasanya tidak terjadi pada perkembangan anak-anak pada umumnya. Anak-anak yang memiliki hambatan atau keterbatasan sering disebut sebagai anak-anak dengan kebutuhan khusus.

Keuntungan dari pendidikan inklusif adalah bahwa semua anak, termasuk anak-anak dengan kebutuhan khusus, dapat berinteraksi satu sama lain secara alami sesuai dengan tuntutan kehidupan sehari-hari di masyarakat, dan kebutuhan pendidikan mereka dapat dipenuhi sesuai dengan potensi masingmasing (Nugroho dan Mareza, 2016, hlm. 148). Pendidikan inklusif mengharuskan sekolah untuk dapat mengoptimalkan kemampuan yang ada pada setiap siswa dengan menerapkan metode pembelajaran yang berpusat pada siswa. Dengan penerapan metode pembelajaran yang berpusat pada siswa ini, hal itu menyebabkan guru kelas menjadi kurang mampu mengoptimalkan perhatiannya kepada setiap siswa, terutama untuk siswa dengan kebutuhan khusus (Rahayu, 2017, hlm. 290). Tujuan pendidikan inklusif adalah pendidikan kebutuhan dasar setiap manusia untuk memastikan hidupnya menjadi lebih bermartabat (Milawati, 2017, hlm. 52). Penerapan pendidikan inklusif juga memiliki konsep dasar. Seperti pernyataan Mastuti (2014, hlm. 3) yang menyatakan bahwa konsep dasar pendidikan inklusif dimaksudkan sebagai sistem layanan pendidikan yang mencakup anak-anak dengan kebutuhan khusus untuk belajar bersama dengan teman-teman sebayanya di sekolah biasa yang dekat dengan tempat tinggal mereka.

Anak berkebutuhan khusus (ABK) atau Special Needs Child adalah anak yang menyimpang dari rata-rata anak normal dalam hal; karakteristik mental, kemampuan sensorik, fisik dan neuromaskular, perilaku sosial dan emosional, keterampilan komunikasi, atau kombinasi dua atau lebih hal di atas; sejauh itu memerlukan modifikasi tugas sekolah, metode pembelajaran atau layanan terkait lainnya, yang bertujuan memaksimalkan potensi atau kapasitasnya (Mangunsong, 2011, hlm. 4). Anak berkebutuhan khusus juga dapat diartikan sebagai anak-anak 
dengan karakteristik khusus yang berbeda dari anak-anak pada umumnya tanpa selalu menunjukkan cacat mental, emosional atau fisik (Ratih dan Afin, 2013, hlm. 14). Menjadi seorang guru mendampingi anakanak berkebutuhan khusus merupakan suatu pekerjaan yang sangat melelahkan (Nasir dkk, 2018, hlm. 2). Selain guru kelas di sekolah inklusif ada juga guru pendamping yang dikenal sebagai shadow teacher yang memiliki peran sangat penting bagi anak berkebutuhan khusus (ABK). Shadow teacher bekerja dengan hati-hati dan tidak obstrusive sehingga tidak mengganggu kelas (Manansala dan Dizon, 2008, hlm. 35).

Adanya masalah tersebut, maka membutuhkan seseorang yang selalu berada di samping anak-anak dengan kebutuhan khusus. Orang tersebut memiliki tugas memberi arahan jika anak tidak memahami pelajaran, dapat disebut sebagai guru pendamping atau shadow teacher. Shadow teacher atau guru pendamping adalah seorang guru yang bekerja secara langsung untuk mendampingi siswa berkebutuhan khusus dan memiliki pengetahuan serta keahlian di bidang anak berkebutuhan khusus yang membantu atau bekerja sama dengan guru sekolah biasa dalam menciptakan pembelajaran inklusif (Yuwono, 2007, hlm. 1). Cara shadow teacher dalam mendampingi siswa berkebutuhan khusus pada saat proses pembelajaran di kelas itu berbeda-beda. Hal ini dikarenakan adanya perbedaan latar belakang dari shadow teacher itu sendiri. Sebagai pendamping siswa berkebutuhan khusus tentunya shadow teacher berperan untuk mendampingi dalam segala aktifitas di sekolah termasuk dalam kegiatan belajar mengajar.

Sebagaimana yang diungkapkan oleh Skjorten dkk (2001, hlm. 27) yang menyatakan bahwa shadow teacher memiliki beberapa peranan diantaranya: 1) membantu siswa berkebutuhan khusus untuk memahami kembali materi yang disampaikan oleh guru di kelas, 2) mendampingi siswa berkebutuhan khusus dalam menyelesaikan tugasnya dengan memberikan instruksi yang mudah dimengerti oleh siswa, 3) membantu menyusun kegiatan yang dapat dilakukan di dalam maupun di luar kelas, 4) mempersiapkan siswa berkebutuhan khusus pada kondisi rutinitas yang berubah prositif, 5) menekankan keberhasilan siswa berkebutuhan khusus dan memberikan reward atas usaha yang dilakukan, dan 6) membantu siswa berkebutuhan khusus dalam segala aktifitas di sekolah yang dibutuhkan.

Shadow teacher atau guru pendamping seharusnya dapat membantu guru kelas dalam mendampingi anak-anak dengan kebutuhan khusus selama proses pembelajaran di kelas, sehingga proses pengajaran dapat berjalan dengan lancar tanpa gangguan (Sulaksono, 2007, hlm. 13). Keterlibatan shadow teacher di sekolah merupakan salah satu kebijakan yang ditawarkan dari sekolah kepada orang tua siswa berkebutuhan khusus. Stubss dalam Juhri AM et al (2016, hlm. 4) menyatakan bahwa kolaborasi antara mitra dalam mengatur kelas inklusif sangat penting untuk mendukung keberhasilan pembelajaran anak berkebutuhan khusus. Sebagaimana hasil wawancara dengan guru pendamping khusus (GPK) di SD Taman Muda Ibu Pawiyatan bahwa:

"Pemilihan shadow teacher di SD

Taman Muda Ibu Pawiyatan orang tua diberi kebebasan untuk menentukan, ada yang mencari dari sekolah itu sendiri, ada yang orang tuanya sendiri yang berperan sebagai shadow teacher hingga pendamping dari luar sekolah seperti mahasiswa, psikolog hingga pendamping yang bukan dari kalangan pendidikan" (Rejeki, wawancara, 02 Agustus 2019).

Dalam kegiatan belajar di kelas sebagian besar siswa berkebutuhan khusus di SD Taman Muda Ibu Pawiyatan didampingi oleh shadow teacher masingmasing. Dalam proses pembelajaran di kelas shadow teacher berperan membantu siswa berkebutuhan khusus untuk 
memahami materi yang disampaikan oleh guru, membantu menghitung pada saat pelajaran matematika hingga menjawab soal yang diberikan oleh guru. Terlepas dari keberagaman latarbelakang shadow teacher yang mendampingi siswa berkebutuhan khusus di sekolah, tentu juga masing-masing shadow teacher memiliki cara yang berbeda-beda dalam membimbing siswa berkebutuhan khusus.

Kriteria utama seorang shadow teacher adalah untuk dapat dan mampu memahami karakteristik dan keragaman anak berkebutuhan khusus, serta memahami prosedur penanganannya dengan cara baik dan benar (Sari dan Rahmah, 2018, hlm. 146). Selain itu, shadow teacher harus memiliki kesabaran yang tinggi, ketulusan, dan juga kemauan karena yang mereka hadapi adalah anakanak yang memiliki karakteristik dan perilaku yang berbeda dari anak-anak normal (Faizah, 2018, hlm. 60). Gardner dalam Iskandar et al (2012, hlm. 29) juga menyatakan bahwa anak-anak dengan kebutuhan khusus pada dasarnya membutuhkan lebih banyak dukungan, kesempatan atau peluang, kepercayaan, perhatian, bimbingan, dan kasih sayang dari lingkungan mereka.

Akan tetapi penjelasan di atas justru malah bertentangan dengan hasil observasi yang dilakukan oleh peneliti, bahwasannya pada saat proses pembelajaran di kelas terlihat shadow teacher yang mendampingi MA (gangguan intelektual ringan) melakukan pendampingan dengan cara yang otoriter dan dengan nada yang keras dan kasar. Shadow teacher dari MA tersebut merupakan ibu kandung dari MA itu sendiri. Dengan pendampingan yang cenderung kasar tersebut membuat MA mengalami tekanan pada saat belajar di kelas dan tidak jarang MA menangis dan keluar kelas pada saat pembelajaran di kelas. Selain itu juga membuat siswa yang lainnya terganggu dengan tindakan shadow teacher tersebut. Hal ini diperkuat melalui penyataan dari guru kelas VI bahwa:
"Tindakan shadow teacher tersebut sering dilakukan dan membuat situasi kelas tidak fokus. Kadang kasihan sama siswa yang lain juga terganggu, cara shadow teacher menjelaskan ke siswanya itu dengan emosi kalau gak cepet paham dengan yang dijelasin. Saya kan guru baru mbak baru 8 bulan mengajar dan menjadi wali kelas disini jadi saya tidak enak untuk menegur shadow teacher tersebut. Seharusnya ya shadow teacher itu sendiri yang menyadari adanya guru di kelas tersebut. Jadi, kesannya siswa itu takutnya sama shadow teacher bukan sama saya sebagai guru kelas" (Nada, wawancara, 27 Agustus 2019).

Dengan demikian tentu yang dilakukan oleh shadow teacher membuat siswa reguler sulit untuk berkonsentrasi dalam kegiatan belajar di kelas, terutama pada saat mengerjakan soal yang membutuhkan konsentrasi tinggi. Hal ini sebagaimana yang ungkapkan oleh Azali Rahmadani Dewi Safitri salah satu siswa reguler kelas VI yang mengatakan bahwa dirinya sering tidak fokus saat mengerjakan soal matematika, mengingat kondisi kelasnya yang tidak kondusif. Hal tersebut bertentangan dengan pendapat Ajuwon (2012, hlm. 100) yang menyatakan bahwa inclusive classroom settings should be strengthened and supported by a cadre of specially trained personnel and other appropriate supportive practices according to the individual needs of the child yang artinya pengaturan ruang kelas inklusif harus diperkuat dan didukung oleh kader personel yang dilatih khusus dan praktik pendukung lainnya yang sesuai dengan kebutuhan setiap anak. Peran ini tercermin dalam bagaimana shadow teacher atau guru pendamping melaksanakan tugas dan tanggung jawabnya. Kinerja shadow teacher atau guru pendamping tersebut akan sangat menentukan kualitas hasil dari pendidikan.

Atas tindakan yang dilakukan oleh shadow teacher tersebut membuat siswa 
reguler memiliki perasaan tidak senang dengan shadow teacher dan juga MA, ini karena kurang fokusnya siswa reguler saat belajar di kelas yang disebabkan pendampingan dari MA membuat siswa lainnya sulit untuk konsentrasi dan dapat berakibat dengan hasil belajarnya. Sedangkan MA selalu mendapatkan nilai yang tinggi atas bantuan shadow teacher pada saat pembelajaran. Meskipun adanya perasaan tidak nyaman dan terganggu guru kelas ataupun wali kelas tidak melakukan tindakan apapun, hal ini karena adanya perasaan tidak enak jika harus menegur shadow teacher tersebut. Begitupun juga dengan siswa reguler, meskipun sering terganggu saat belajar di kelas, namun perasaan tidak nyaman dan tidak suka tersebut hanya diungkapkan dengan sesama teman reguler tanpa sepengetahuan dari shadow teacher maupun siswa berkebutuhan khusus (MA) tersebut.

Sekolah memberikan pelatihan kepada para guru dan para staf atau pemangku kepentingan di sekolah, tentang bagaimana cara berperilaku dan bagaimana cara menghadapi siswa dengan kebutuhan khusus dan siswa normal di sekolah dengan cara yang sopan dan manusiawi (Prastiyono, 2013, hlm. 117). Shadow teacher di SD Taman Muda Ibu Pawiyatan juga sudah diberikan pelatihan edukasi atau bimbingan setiap satu bulan sekali. Hal ini bertujuan untuk mengoptimalkan dalam mendampingi siswa berkebutuhan khusus sesuai dengan kebutuhannya. Tetapi, shadow teacher tidak semuanya dapat melaksanakan dengan baik tentang prosedur atau pola pendampingan terhadap siswa berkebutuhan khusus sesuai dengan yang didampinginya. Salah satunya termasuk shadow teacher dari MA, meskipun sudah diberikan pelatihan dan bimbingan tidak menjalankan dengan baik sebagaimana peran dari shadow teacher sendiri.

Di sisi lain, hal tersebut seharusnya menjadi perhatian khusus bagi sekolah terutama wali kelas yang mengampu kelas tersebut, karena terjadi pada saat proses pembelajaran di kelas. Sebaiknya wali kelas tersebut memberikan teguran kepada shadow teacher untuk tidak bertindak di luar perannya sebagai pendamping siswa berkebutuhan khusus. Hal ini sejalan dengan pendapat Zakia (2015, hlm. 110) bahwasannya dilihat dari tugas dan fungsi shadow teacher atau guru pendamping di sekolah inklusif, rata-rata mereka masih belum menerapkannya dengan baik sehingga mempengaruhi layanan untuk anak berkebutuhan khusus yang berada di sekolah inklusif. Kemampuan shadow teacher dalam memahami siswa berkebutuhan khusus masih kurang, masih ada kebutuhan untuk memperdalam pengetahuan tentang anak berkebutuhan khusus dan program inklusif di sekolah.

Untuk menghindari keadaan tersebut sebagian dari orang tua siswa reguler di SD Taman Muda Ibu Pawiyatan yaitu pada siswa kelas IV membuat kesepakatan dengan orang tua siswa berkebutuhan khusus agar tidak melakukan pendampingan pada siswa berkebutuhan khusus di kelas IV. Hal ini sejalan dengan pendapat Alimin (2011, hlm. 166) yang menyatakan bahwa kelemahan yang terjadi dalam pendidikan anak-anak berkebutuhan khusus sejauh ini diduga disebabkan oleh ketidakcocokan antara layanan pendidikan dan kebutuhan masing-masing anak. Di sisi lain, orang tua atau wali dari kelas IV tidak mengizinkan anak berkebutuhan khusus didampingi oleh shadow twacher. Hal ini dilakukan karena mengakibatkan kecemburuan sosial dan juga adanya stigma orang tua dari siswa reguler yang beranggapan bahwa adanya pendamping bagi siswa berkebutuhan khusus akan menganggu konsentrasi siswa yang tidak didampingi dalam kegiatan belajar di kelas. Jadi, dalam penelitian ini ada beberapa masalah yang dialami oleh shadow teacher atau guru pendamping dalam memberikan layanan bagi siswa dengan kebutuhan khusus. Secara administratif, guru kelas atau wali kelas tidak melakukan evaluasi secara optimal dengan melihat adanya permasalahan yang 
ada di kelas VI tersebut. Hal ini disebabkan karena guru kelas atau wali kelas merasa tidak enak untuk menegur shadow teacher yang tidak sesuai dengan perannya. Jika hal tersebut berulang-ulang terjadi maka akan mengakibatkan siswa yang lain terganggu dan kelas menjadi tidak nyaman untuk proses pembelajaran.

\section{KESIMPULAN}

Berdasarkan hasil penelitian dan pembahasan di atas maka dapat disimpulkan bahwa shadow teacher secara optimal mendedikasikan diri dalam memberikan pendampingan yang baik kepada siswa berkebutuhan khusus. SD Taman Muda Ibu Pawiyatan Yogyakarta sebagai sekolah inklusi yang memberikan kebebasan kepada orang tua siswa berkebutuhan khusus sebagai shadow teacher. Diantaranya ada yang orang tuanya sendiri yang berperan sebagai shadow teacher hingga pendamping dari luar sekolah seperti mahasiswa, psikolog, hingga pendamping yang bukan dari kalangan pendidikan. Terlepas dari keberagaman dan latar belakang shadow teacher yang mendampingi siswa berkebutuhan khusus di sekolah, tentu juga masing-masing shadow teacher memiliki cara yang berbeda-beda dalam membimbing siswa berkebutuhan khusus. Data di lapangan memperoleh fakta bahwa terdapat shadow teacher yang mendampingi MA (gangguan intelektual ringan) melakukan pendampingan pada saat proses pembelajaran di kelas dengan cara yang otoriter dan dengan nada yang keras dan kasar. Hal tersebut kemudian membuat siswa berkebutuhan khusus menjadi tertekan dan juga menganggu kegiatan belajar mengajar di kelas.

\section{DAFTAR PUSTAKA}

Ajuwon, P. M. (2012). General Education Pre-Service Teachers Perceptions of Including Students with Disabilities in Their Classrooms. Iternational Journal of Special Education, 27 (3), 100-107.
Alimin, Z. (2011). Model Pembelajaran Anak Tunagrahita (Intellectual Disability) Melalui Pendekatan Konseling (Penelitian Tindakan Kolaboratif dalam Upaya mengembangkan Anak Tunagrahita Mencapai Perkembangan Optimum). Jurnal Asesmen dan Intervensi Anak Berkebutuhan Khusus, 10 (2), 165175.

AM, Juhri. Wibowo, S. B,. dan Syutharidho. (2016). Pengembangan Model Lesson Study untuk Sekolah Inklusi SMP Negeri di Kota Metro. Jurnal Lentera Pendidikan, LPPM UM METRO, 1 (1), 1-15.

Berry, R.A.W. (2006). Inclusion, Power and Community: Teachers and Student Interpret The Language of Community in an Inclusion Classroom. American Educational Research Journal, 489-529.

Elisa dan Syafrida. (2013). Sikap Guru Terhadap Pendidikan Inklusif ditinjau dari Faktor Pembentuk Sikap. Surabaya: Fakultas Psikologi Universitas Airlangga.

Faizah, N. M. (2018). Motivasi Pengabdian Shadow Teacher sebagai Pendidik di SD Muhammadiyah 16 Surabaya Perspektif Etika Deontologi dan Teleologi. Surabaya: Skripsi Universitas Islam Negeri Sunan Ampel.

Hasil Observasi pada Pembelajaran Matematika di SD Taman Muda Ibu Pawiyatan Yogyakarta Kelas VI, pada Tanggal 27 Agustus 2019, Pukul 07:37 WIB.

Hasil Wawancara dengan Azali Rahmadani Dewi Safitri selaku Siswa Reguler Kelas VI di SD Taman Muda Ibu Pawiayatan Yogyakarta, pada tanggal 27 Agustus 2019, Pukul 12:30 WIB di depan Ruang Kepala Sekolah. Hasil Wawancara dengan Nyi Dr. Sri Rejeki selaku Guru Pendamping Inklusif (GPK) di SD Taman Muda Ibu Pawiayatan Yogyakarta, pada 
Tanggal 02 Agustus 2019, Pukul 09:40 WIB di Ruang TU.

Hasil Wawancara dengan Nyi Izzatun Nada selaku Pamong Kelas VI di SD Taman Muda Ibu Pawiyatan Yogyakarta, pada Tanggal 27 Agustus 2019, pukul 12:30 WIB di depan Ruang Kepala Sekolah.

Iskandar, R. dkk. (2012). Pendidikan Inklusi di Sekolah Dasar Negeri Lebak Bulus 06 Pagi DKI Jakarta. Jurnal Pengabdian Masyarakat: Ilmu Keguruan dan Pendidkan, 21-31.

Manansala, M. A., dan Dizon, E. I. (2008). Shadow Teaching Scheme for Children with Autism and Attention Deficit-Hyperactivity Disorder in Regular Schools. Education Quarterly, 66 (1), 34-49.

Mangunsong, F. (2011). Psikologi dan Pendidikan Anak Berkebutuhan Khusus. Jakarta: Penerbit LPSP3 UI.

Mastuti, D. (2014). Kesiapan Taman Kanak-Kanak dalam Penyelenggaraan Kelas Inklusi dilihat Program Kegiatan Pembelajaran. Journal of Early Childhood Education Papers, 3 (1), 1-8.

Milawati, W. W. (2017). Strategi Guru Pendamping Khusus dalam Pembelajaran Anak Berkebutuhan Khusus di Pelayanan Inklusi (Studi Kasus SDN Sumbersari 1 Kota Malang). Malang: Skripsi Universitas Islam Negeri Maulana Malik Ibrahim.

Miles, Metthew B, A, et al. (2014). Qualitative Data Analysis, A Methods Sourcebook. Third Edition. United State of America: Stage Publications, Inc.

Nasir, A., dkk. (2018). The Experience of Shadow Teachers in Helping Children WTH Special Needs in Telogo Patut Elementary School I Gresik. Jurnal Ilmu Keperawatan, 6 (1), 1-9.

Nugroho, A. dan Mareza. L. (2016). Model dan Strategi Pembelajaran Anak Berkebutuhan Khusus dalam Setting Pendidikan Inklusi. Jurnal Pendidikan Dasar PerKhasa, 2 (2), 145-156.
Peraturan Menteri Pendidikan Nasional Nomor 70 tahun 2009 tentang Pendidikan Inklusif (Pensif) bagi Peserta Didik yang Memiliki Kelainan dan Memiliki Potensi Kecerdasan dan/atau Bakat Istimewa.

Prastiyono. (2013). Implementasi Kebijakan Pendidikan Inklusif (Studi di Sekolah Galuh Handayani Surabaya). Jurnal Administrasi Publik, 11 (1), 117-128.

Rahayu, T. (2017). Burnout dan Coping Stress pada Guru Pendamping (Shadow Teacher) Anak Berkebutuhan Khusus yang Sedang Mengerjakan Skripsi. PSIKOBORNEO, 5 (2), 290-300.

Rahmaniar, F. A. (2016). Tugas Guru Pendamping Khusus (GPK) dalam Memberikan Pelayanan Pendidikan Siswa Berkebutuhan Khusus di Sekolah Inklusif SD Negeri Giwangan Yogyakarta. Jurnal Widia Ortodidaktika, 5 (12), 1252-1263.

Sari, M. W. F., dan Rahmah, T. H. (2018). Pengaruh Kompetensi Guru Shadow Terhadap Indikator Penilaian pada Sekolah Inklusi MI Terpadu ArRoihan. Proceedings of The ICECRS, 1 (3), 143-154.

Skjorten, D. Miriam. (2001). EducationSpecial Needs Education An Intoduction. Oslo: Unfub Forlag.

Smith, J. David. (2012). Sekolah Inklusif. Bandung: Nuansa.

Sugiyono. (2010). Metodologi Penelitian Pendidikan. Bandung: Alfabeta.

Sulaksono, Aditya. (2007). Gambaran Burn Out pada Guru Pendamping Anak Autis di Sekolah Dasar Negeri 04 Pagi Jakarta Timur : SD Penyelenggara Pendidikan Inklusi. Jakarta: Skripsi Universitas Islam Negeri Syarif Hidayatullah.

Umroh, I. L. (2019). Peran Orang Tua dalam Mendidik Anak Sejak Dini Secara Islami di Era Milenial 4.0. TA'LIM: Jurnal Studi Pendidikan Islam, 2 (2), 208-225. 
Wardah, E. Y. (2019). Peranan Guru Pembimbing Khusus Lulusan NonPendidikan Luar Biasa (PLB) Terhadap Pelayanan Anak Berkebutuhan Khusus di Sekolah Inklusi Kabupaten Lumajang. Jurnal Pendidikan Inklusi, 2 (2), 93-108.

Wardani, dkk. (2018). Kinerja Guru Pendamping Khusus SD Inklusi, Jurnal Manajemen Mutu Pendidikan, $6(1), 1-13$.

Yasa, R. B. \& Julianto. (2017). Evaluasi Penerapan Pendidikan Inklusi di Sekolah Dasar di Kota Madya Banda Aceh dan Kabupaten Pidie. Gender Equality: International Journal of Child and Gender Studies, 3 (2), 120135.

Yuwono, Joko. (2007). Pendidikan Inklusif. Bahan Ajar: Atmajaya.

Zakia, D. L. (2015). Guru Pembimbing Khusus (GPK): Pilar Pendidikan Inklusi. Artikel dipresentasikan di Universitas Sebelas Maret dan ISPI Wilayah Jawa Tengah. 